\title{
LA INTIMIDAD DEL ESTUDIO COMO FORMA DE VIDA
}

\author{
The intimacy of study as a way of life
}

\author{
Fernando BÁRCENA ORBE \\ Universidad Complutense de Madrid. España. \\ fbarcena@ucm.es \\ bttps://orcid.org/0000-0002-8982-8028
}

Fecha de recepción: 08/04/2019

Fecha de aceptación: 17/05/2019

Fecha de publicación en línea: 05/09/2019

\section{RESUMEN}

El objetivo de este ensayo es una exploración de la intimidad del estudio considerado como una forma de vida. El punto de partida que sirve de inspiración aquí es doble. Por una parte, la antigua tradición grecolatina que entendía la actividad filosófica como un ejercicio espiritual (como un arte de vivir o como un cuidado de sí). Desde esta perspectiva, el estudio (al mismo tiempo una actividad que se realiza y un lugar de exilio estudioso) -referido a esta noción griega de «espiritualidad»-consiste en la experiencia por medio de la cual el sujeto (estudioso) efectúa en sí mismo las transformaciones necesarias para tener acceso a la verdad de sus asuntos, donde se quiebran las relaciones tradicionales del adentro y del afuera, lo interior y lo exterior. Lo que aquí se postula, entonces, es que la verdad no se ofrece al sujeto como un mero acto de conocimiento, sino que es preciso que se modifique, transforme y se convierta en distinto de sí mismo para tener derecho de acceso a la verdad. Se establece, entonces, una relación muy diferente -a la que predomina en los discursos pedagógicos contemporáneos de la llamada sociedad del aprendizaje (que ponen el acento en el aprender, pero no en el estudiar)- entre el sujeto y el saber. Por otro lado, este texto se sirve de una imagen determinada, que trata de dar cuenta de un aspecto central de la intimidad del estudio: como Penélope, que teje y desteje cada día una tela funeraria mientras espera el regreso de Ulises, para así poder resistirse a la presión de sus acosadores, el estudio es una actividad interminable que, en cada jornada, el estudioso repite los mismos gestos (en el leer, el pensar y el escribir), gestos que le 
permiten sostenerse en la larga fatiga del estudio y sustraerse a la presión ejercida por una idea de la educación que ha de estar volcada siempre a los resultados y a las utilidades. En este ensayo se explora, de acuerdo con todo esto, el estudio como una actividad interminable donde se ejerce el tiempo libre en una modalidad de exilio estudioso, en la que la práctica de la lectura y la escrita de anotaciones sostienen al estudioso en la larga fatiga del estudiar.

Palabras clave: intimidad del estudio; estudio y tiempo libre; aprendizaje (sociedad del); exilio estudioso; cuaderno de notas; profesor.

\section{ABSTRACT}

The aim of this essay is an exploration of the intimacy of the study as a way of life. The starting point for inspiration here is twofold. On the one hand, the ancient Greco-Latin tradition that understood philosophical activity as a spiritual exercise (as an art of living or as self-care). From this perspective, study (both an activity that takes place and a place of studious exile) -referred to this Greek notion of "spirituality»consists of the experience through which the subject (studious) carries out in himself the transformations necessary to have access to the truth of his affairs, where the traditional relations of the inside and the outside, inner and outward. What is postulated here, then, is that truth is not offered to the subject as a mere act of knowledge, but that it must be modified, transformed and become distinct from itself in order to have the right of access to truth. Thus, a very different relationship is established -to that which predominates in the contemporary pedagogical discourses of the so-called learning society (which emphasizes learning, but not studying)- between the subject and knowledge. On the other hand, this text makes use of a certain image, which tries to account for a central aspect of the intimacy of study: Like Penelope, who makes and unmakes a funerary cloth every day while awaiting the return of Ulysses, so as to be able to resist the pressure of his harassers, study is an interminable activity that, in each day, the atudious repeats the same gestures (in reading, thinking and writing), gestures that allow him to sustain himself in the long fatigue of study and to escape the pressure exerted by an idea of education that must always be focused on results and utilities. In this essay, study is explored, in accordance with all this, as an interminable activity where free time is exercised in a modality of studious exile, in which the practice of reading and writing notes sustain the atudious in the long fatigue of studying.

Key words: intimacy of study; study and free time; learning (society of); studious exile; notebook; teacher. 


\section{INTRODUCCIÓN}

El objetivo de este ensayo es cierta exploración del estudio considerado como una forma de vida. ${ }^{1}$ Hablaremos del estudio para referirnos tanto a un tipo de actividad que se realiza como a un espacio (por ejemplo, pero no únicamente, el cuarto de estudio) donde el estudioso se exilia.

El punto de partida aquí es doble. Por una parte, con la expresión forma de vida remito a esa antigua tradición grecolatina que entendía la actividad filosófica como un «ejercicio espiritual», como un "arte de vivir» (Pierre Hadot, 2001 y 2006; Foucault, 2001, 2008, 2009 y 2014; Greish, 2005; Nehamas, 2005; Pavie, 2012; Pérez Cortés, 2004), o como un "cuidado de sí» (epimeleia heautou). En su curso del Collège de France Hermenéutica del sujeto, Foucault señala que si la filosofía es la forma de pensamiento que se interroga acerca de lo que permite al sujeto tener acceso a la verdad, la «espiritualidad» no sería sino «la búsqueda, la práctica, la experiencia por las cuales el sujeto efectúa en sí mismo las transformaciones necesarias para tener acceso a la verdad» (Foucault, 2001, p. 16). En el estudio, como veremos, también se operan esas transformaciones en el sujeto estudioso. La tradición antigua que puso el énfasis en la importancia del "cuidado de sí», frente al "conocimiento de sí» (gnothi seauton), y en la preeminencia, finalmente olvidada por la modernidad, del "momento socrático" (que pone el acento en la transformación de uno mismo), frente al "momento cartesiano" (que pone el acento en el conocimiento), lo que viene a sugerirnos es que lo que los griegos denominaban «espiritualidad", dicho con Foucault, "postula que la verdad no se da al sujeto como un mero acto de conocimiento [...] Postula que es preciso que el sujeto se modifique, se transforme, se desplace, se convierta, en cierta medida y hasta cierto punto, en distinto de sí mismo para tener derecho de acceso a la verdad» (Foucault, 2001, p. 17). En este texto no se podrán explorar, por la enorme amplitud del tema, todas las implicaciones y ramificaciones filosóficas de este asunto. Lo que sí se pretende mostrar es que el vida estudiosa es una modalidad de relación del sujeto consigo mismo que define un cierto arte de vivir y que concreta o materializa cierta configuración espiritual, en el sentido señalado.

La expresión "forma de vida» la usa frecuentemente Giorgio Agamben:«Una vida que no puede separarse de su forma es una vida para la cual, en su modo de vivir, está en juego el vivir mismo» (Agamben, 2017, p. 233). Aplicada esta fórmula al caso del estudio, diremos que el estudioso, en su afán, hace de su actividad (el estudio) un estilo de vida que conforma su subjetividad como estudioso. Me interesa, pues, destacar especialmente la dimensión intima de esa particular forma de vida. "Íntimo» (del latín, intimus), es lo «muy» o lo «más interior». François Jullien

1. Quiero agradecer a Diana Suárez la atenta, cuidadosa, cálida y estudiosa lectura de este ensayo que, entre otras cosas, me advirtió de algunas erratas que yo no había apreciado en el texto. 
sugiere que lo íntimo consiste en una experiencia que nos retrae de los otros y nos coloca en estrecha relación con nosotros mismos. En la experiencia de lo íntimo se quiebran las relaciones tradicionales del adentro y del afuera, ubicando al sujeto es un retiro a salvo de las miradas de los demás. Intimar con alguien, o con algo, sería abrir un espacio más profundo dentro de uno que permite la entrada de ese alguien o de ese algo: "No es virtud ni cualidad, no tiene determinación ni objetivo, en suma, [...] no tiene fin" (Jullien, 2016, p. 26). Hablar de intimidad, por tanto, no es hablar de asuntos meramente privados, sino de intensidades. Se puede vivir sin intimidad, por supuesto, pero esto es así precisamente porque «la intimidad sólo es necesaria para disfrutar de la vida” (Pardo, 1996, p. 30).

Por otro lado, mi aproximación a la intimidad del estudio se sostiene en una imagen determinada. Como Penélope, que teje y desteje cada día una tela funeraria para su suegro Laertes, mientras espera el retorno de Ulises, el estudio es, también, una actividad interminable en la que, en cada jornada, el estudioso repite los mismos gestos (en el leer, el pensar y el escribir, que son ejercitaciones espirituales, en el sentido aludido). El gesto de Penélope es una audacia: en ese acto resiste el acoso de los molestos pretendientes. Estudiar es un gesto de resistencia. El estudio, diremos, no tiene fin, y además su final no se atisba en el horizonte. Es una vocación, e incluso podríamos decir que es una devoción que da forma a un modo de ser. Insistamos en el hecho de que, en el horizonte de ese énfasis en el "cuidado de sín, en esa importante tradición que atisbó el ejercicio filosófico como una forma de vida, como un ejercicio espiritual y, en definitiva, como una forma de autoeducación, el estudio (como actividad que se realiza y como una forma de exilio) configura en el sujeto un arte de vivir que, al replegarlo como estudioso en sí mismo, al mismo tiempo lo acerca a su propia subjetividad para mirar el mundo (que estudia) de otro modo.

El tema de este ensayo, conviene decirlo de nuevo, es infinito, y no podré dar cuenta aquí de todas sus ramificaciones, históricas, literarias y filosóficas. Conviene, no obstante, recordar brevemente algunas contribuciones, que quizá son ya bien conocidas. Así, Ortega y Gasset (1974, p. 21), en la primera lección del curso Unas lecciones de Metafísica, ya apuntaba al estrecho vínculo entre el estudiar (del estudiante) y la íntima necesidad que ha de tenerse del estudio, para que no resulte algo espurio. Ortega refiere una menesterosidad (del estudiante) que emerge de su curiosidad intrínseca, y que se vuelca en un cuidado, en una "preocupación». Paulo Freire se refería a la dificultad del trabajo del estudio, que «exige de quien lo hace una postura crítica, sistemática. Exige una disciplina intelectual que no se adquiere sino practicándola» (Freire, 2001, p. 47). El punto de vista de Pierre Bourdieu es más complejo y muy crítico con lo que denominó la «disposición escolástica». Siguiendo a Erwin Panofsky (2007), Bourdieu cuestionó el moralismo de la razón escolástica, que vincula con la burguesía y su forma de vida carente de preocupaciones materiales. Su crítica viene asociada a su rechazo de las pretensiones de una Razón soberana y 
a la supuesta libertad del creador. En sus Méditations pascaliennes, Bourdieu manifiesta una actitud muy alejada del perfil del productor de conocimiento tradicional, como él lo denomina, recluido en su «torre de marfil» (Bourdieu, 2003, pp. 23 y ss.), y ajeno a las condiciones sociales que le proporcionan los privilegios necesarios para poner en práctica su actividad. En definitiva, Bourdieu trata de desmontar de alguna manera esa mirada indiferente a contextos y fines prácticos de los ejercitantes en el ocio estudioso propio de la Scholé, cuya forma institucionalizada sería la "escuela». Finalmente, desde el plano de la crítica cultural, el estudio forma parte de una historia de las ideas que vincula al estudioso con la "vie du lettré», tal y como la refiere, en un ensayo del mismo título, William Marx. Este libro, narra la vida de estudiosos y letrados que "no pertenecen al orden de las cosas" (Marx, 2009, p. 11), seres que leen libros y los coleccionan, que los editan, comentan, anotan, que los transmiten y los enseñan a las nuevas generaciones, pues «el pasado no se transmite por sí mismo. Hay que ayudarlo» (Marx, 2009, p. 18).

Algunos interrogantes que podemos formularnos, a título meramente orientativo, son los siguientes: ¿En qué consiste una vida estudiosa, una vida dedicada a estudiar? ¿Cuáles son los ritos del estudio, sus ritmos, sus modos, sus maneras y sus hábitos? ¿Cómo es su cuarto de estudio del estudioso? ¿Cómo se organiza el tiempo y los horarios? ¿Cómo son las noches de los estudiosos y cómo sus jornadas? Estas preguntas sugieren una tesis que conviene explicitar cuanto antes, pues la misma proporciona un contraste y una tensión con nuestro presente.

En el contexto del discurso de la «sociedad del aprendizaje» sin duda se pueden aprender muchas cosas, pero sin necesidad de haberlas estudiado con atención y demoradamente, en el sentido en que consideraré aquí la palabra «estudio». Al menos en lo que se refiere a las instituciones de educación, nuestra época se siente orgullosa de nociones tales como «aprendizaje» (y otras, como «aprender a aprender», "aprender a lo largo de toda la vida", "emprendedurismo"), pero vuelve impensable la palabra estudio. Como ha escrito Masschelein (2001):

La noción de aprendizaje (y de aprender a aprender) ha llegado hoy a ser la noción central en el discurso educativo y sociopolítico. Por una parte, el aprendizaje tiene que ser considerado como la actividad socialmente más importante de la que depende la supervivencia de los individuos y la sociedad. Por otro lado, la misma realidad pedagógica es objetivada en términos de aprendizaje (y no en términos de Bildung, por ejemplo) (p. 12).

Desde esa fecha, sino antes, la revisión de lo que Gert Biesta (2015) llamó "auge del lenguaje del aprendizaje» ha venido promoviendo un replanteamiento de la misma idea de la experiencia educativa. La noción de «estudio» ha resultado ser uno de los tópicos que recientemente más se están explorando (Lewis, 2003; Arsenjuk y Koerner, 2009; Backer y Lewis, 2015; Rocha, 2015; Hodgson, 2016; Ruitemberg, 2017). Gert Biesta, al preguntarse por la naturaleza del sujeto de la educación (¿Aprendiz, hablante, estudiante?) sugiere que «quien es el sujeto de la educación es convocado 
al estudio y, así, en el sentido más general, se ha convertido en un estudiante» (Biesta, 2011, 158). No es al aprender hacia lo que es convocado, sino al estudio. El matiz es interesante.

La indagación que propongo ha de conducirnos al análisis detenido de un concepto (el estudio) que tiene que ver tanto con una actividad como con un espacio (el Studiolo, cuyo origen se remonta al renacimiento italiano) habilitado para que el estudioso (o el estudiante) se exilie un poco al margen del ritmo habitual del mundo. Entregado a sus afanes, el estudioso establece una suerte de intimidad con algo de lo que no le resulta fácil desasirse, ejercitándose en una soledad en la que se instruye en el arte de la lectura y la escritura de anotaciones. Las anteriores preguntas, entonces, dan cuenta de una particular fenomenología del estudio, una actividad enlazada con la larga historia en la que la vida estudiosa parece insertarse (Fumaroli, 2013; Marx, 2009; Thornton, 1997).

\section{El gesto de Penélope}

Penélope espera el regreso de Ulises. La espera es ciertamente dolorosa. Penélope duerme constantemente; de este modo el tiempo corre más deprisa. Mientras duerme, la visitan grandes ensueños que anuncian la salvación de Telémaco y el regreso de Ulises. Telémaco, sin padre, va en su busca, para que el orden y la ley retornen a la casa, infestada de los pretendientes de Penélope, que amenazan con arruinarlo todo. Cuando Ulises regrese, el castigo que recibirán será terrible.

Así vive Penélope: «Envuelta más que ningún otro personaje de la Odisea en sombras, en dulzura, en la tranquilidad y la incertidumbre de lo inconsciente» (Citati, 2008, p. 255). Mientras tanto, teje y desteje una tela extensa para su suegro Laertes, una obra maestra de engaño y artesanía: "Por el día tejía en el telar la gran tela, y por las noches lo destejía, poniendo a su lado antorchas» (Homero, 2004, II, 105-107). En esa espera, tejer y destejer hace que el tiempo de la espera duela menos. Encerrada en su cárcel de Ítaca, Penélope teje y desteje: este es su gesto, su afán y su trabajo en una espera que parece interminable. La reina de Ítaca hace lo posible por mantener cada cosa en su lugar. Insiste (en su tejer) y resiste (en su afán). Cada jornada inicia de nuevo su labor. Repite los mismos gestos una y otra vez. Su insistencia es admirable. Ni olvida (a Ulises) ni quiere olvidar. Conserva su memoria. En ese gesto suyo, Penélope resiste ante la fea presión de todo lo que viene de afuera. Necesita resistir porque ama a Ulises, y lo ama porque lo recuerda, y lo recuerda porque ama: es amando como (se) recuerda y es recordando como (se) ama. Penélope, entristecida por la ausencia de Ulises, sufre y llora porque sin él se siente incompleta. Nada puede llenar esa terrible ausencia del amado. Sentirse incompleta hace de su existencia una errata de su propia historia, un vacío.

El trabajo de Penélope es una buena metáfora para pensar lo que significa dedicarse a una vida estudiosa, que hace y deshace constantemente lo mismo en el pensar, el leer y el escribir, y también en todo arte (música, pintura, escultura). 
Así se empleó para concebir la naturaleza del pensamiento, pues pensar es hacer y deshacer constantemente e insistir una y otra vez sobre lo ya pensado. Pensar, decía Arendt, es «como la labor de Penélope, que cada mañana destejía lo que había hecho la noche anterior» (Arendt, 2002, p. 110). El poeta Paul Valéry, a quien Arendt cita en su libro, también escribió en uno de sus cuadernos: "Mi trabajo es de Penélope, este trabajo en estos cuadernos — pues se trata de salir del lenguaje corriente y de recaer en él, de salir del lenguaje — en general — es decir, del — camino, y de volver a él» (Valéry, 2017, p. 9).

Para Penélope, ese tejer y destejer es una astucia a la altura del amor que siente por el audaz Ulises. El estudioso también hace y deshace (en el pensamiento, la lectura, la escritura) constantemente, y parece que siempre está comenzando. Si el estudioso transmite después a sus perplejos estudiantes lo que ha estado haciendo en su cuarto de estudio, con toda probabilidad se dará cuenta de que ha de recomenzar todo de nuevo. Dicho así, parece un trabajo absurdo, un castigo; como el de un Sísifo condenado a empujar eternamente una roca hasta lo alto de una montaña, desde donde la piedra volverá a rodar cayendo por su propio peso: «Su trabajo es el de Sísifo, siempre recomenzando", dice William Marx (2009, p. 13). Citemos a Homero (2004):

Y vi también a Sísifo, que padecía intensos dolores, sosteniendo una enorme roca con sus dos manos. Apoyándose con sus manos y pies, empujaba hacia arriba en la colina el pedrusco. Mas cuando estaba a punto de coronar la cima, entonces una violenta fuerza lo derribaba hacia atrás. Y luego la impúdica piedra rodaba hasta el llano. Y él, de nuevo, volvía a transportarla con titánico esfuerzo. El sudor le brotaba y manaba de todos sus miembros, y la polvareda lo envolvía desde la cabeza a los pies (XI, 594-601).

Las imágenes que acabo de ofrecer contrastan con el mundo de nuestros entornos sociales y educativos inmediatos. El estudio, que fue una práctica históricamente datada asociada a las artes del leer para escribir, como dice Sloterdijk (2012), ha perdido ya su antigua importancia. Ese estudioso es una figura a contratiempo: un ser que encuentra su refugio en su cuarto de estudio y que vagabundea de libro en libro, tomando múltiples anotaciones en cuadernos. Lo vemos entregado en cuerpo y alma a una interminable y fatigosa actividad cuyo final no se atisba, y que en absoluto es productiva.

Con el auge de los nuevos medios electrónicos, el estudio, como actividad afanosa, ha perdido su misterio y su "aura». El estudio (actividad), asociada al espacio donde se estudia, no parece ya tener mucha relevancia como forma de vida universitaria que comparten estudiantes (alumnizados) y profesores. Ese espacio fijo, siempre el mismo, no existe, o no parece ser ya necesitado. Hemos perdido la lectura atenta, el subrayado de los libros, los cuadernos de anotaciones y las lecturas y escrituras repetidas. El espacio físico del estudio ha perdido su preeminencia para las prácticas y los ejercicios que acompañan los trabajos del espíritu: «El actual productor de textos en pantalla ha dejado atrás la noción de un espacio 
físico, y ello para instalarse concentradamente en el dominio de lo virtual» (Flor y Escandell, 2014, p. 15). No parece tener, en fin, significado alguno el espacio físico y material del estudio como un observatorio destinado a examinar la propia vida o estudiar el mundo. El siguiente fragmento de Confesiones de un pequeño filósofo, de Azorín (2007), sin duda hoy nos resulta extraño:

Lector: yo emborrono estas páginas en la pequeña biblioteca del Collado de Salinas. Quiero evocar mi vida. Es media noche; [...] Yo estoy sentado ante mi mesa; sobre ella hay puesto un velón con una redonda pantalla verde que hace un círculo luminoso sobre el tablero y deja en una suave penumbra el resto de la sala. Los volúmenes reposan en sus armarios; apenas si en la oscuridad destacan los blancos rótulos que cada estante lleva —Cervantes, Garcilaso, Gracián, Montaigne, Leopardi, Mariana, Vives, Taine, La Fontaine - a fin de que me sea más fácil recordarlos y pedir, estando ausente, un libro. Yo quiero evocar mi vida; en esta soledad, entre estos volúmenes, que tantas cosas me han revelado, en estas noches plácidas, solemnes, del verano (pp. 52-53).

\section{NO HABLAR «EN GENERAL»: DEL APRENDER Y DEL ESTUDIAR}

Roland Barthes dictó en 1978 un seminario en el Collège de France titulado La preparación de la novela. El deseo de escribir (una novela) es el principio organizador de dicho seminario, y el modelo de la codiciada novela de Barthes es, entre otras, En busca del tiempo perdido de Marcel Proust. Barthes moriría en 1980 como consecuencia de un accidente de tráfico, y su novela no quedaría escrita. El seminario es la puesta en escena de un "como si» Barthes fuese a escribirla. Conocemos, por algunas notas publicadas póstumamente, su anhelo de escribirla: «¿Todo esto significa que voy a escribir una novela? No sé. No sé si será posible llamar novela a la obra que quiero escribir y que deseo que rompa con la naturaleza intelectual de mis textos anteriores» (Sarlo, 2005). Sus dudas e interrogantes tienen un aroma netamente proustiano, pues Proust también había escrito: «La pereza o la duda o la impotencia refugiándose en la incertidumbre sobre la forma del arte. ¿Debo hacer una novela, un estudio filosófico? ¿Soy novelista?» (Proust, 2017, pp. 49-50). Barthes observa que no se aburre jamás cuando las personas hablan de su oficio, «de los problemas de su oficio cualquiera que sea. Desgraciadamente, la mayor parte del tiempo se sienten obligados a limitarse a una conversación general, (Barthes, 2005, p. 58). En su seminario, Barthes habla del oficio al que desearía poder dedicarse (escribir una novela) y, desde luego, no habla en general. Y es que de algunas cosas no basta con hablar «en general». Una vida dedicada al estudio es una de esas cosas.

Este ensayo tiene su propia genealogía. Todo comenzó con un encargo. Había sido yo invitado a participar a dos encuentros internacionales en dos ciudades de 
Brasil $^{2}$, y se me había solicitado un texto sobre la vida estudiosa, sugiriéndoseme que tratase de llevar el asunto hacia la figura del oficio del profesor que tiene vocación por el estudio. El encargo me resultó, a la vez que provocador y atractivo, nada fácil. Para uno de esos encuentros ("Elogio del estudio»), se nos envió un documento breve (escrito por Maximiliano Valero López) con el fin de centrar nuestras conversaciones posteriores. Allí se aludía a la diferencia entre aprender y estudiar, sobre la que luego volveré, en estos términos:

La palabra aprender enuncia básicamente el gesto del gato que caza al ratón, del policía que atrapa al ladrón, o del aprendiz que se esmera por capturar un determinado saber. En la órbita de esta expresión encontramos términos como aprensión, presa, o empresa. La palabra estudio proviene del latín «studium» con el significado de empeño, aplicación, celo, ansia, cuidado, desvelo, poseyendo también el sentido de afecto ("studia habere alicuius» quería decir "gozar del afecto de alguien»). Hablar de estudiar algo sin agrado habría sido para los latinos un contrasentido, al punto que, para decir que algo debía ser hecho por mera obligación, utilizaban la expresión «non studio, sed officio», es decir, «no por agrado, sino por obligación». [...] La palabra aprender expresa el deseo de tomar algo del mundo, mientras que el término estudio señala, sobre todo, el deseo de colocarse en relación a algo, cuidarlo y prestarle atención. En ese sentido, podría decirse que el estudioso no se sirve de aquello que estudia, sino que, por el contrario, se desvive por ello, le dedica su vida, gasta su vida en eso (Citado por Larrosa, 2018, p. 439).

La distinción entre aprender y estudiar me pareció de lo más exacta y dotada de una gran fortaleza heurística. El propio Jorge Larrosa cita, como acabamos de leer, este fragmento en un reciente libro suyo sobre el oficio de profesor, y en otra obra suya podemos leer algo que tiene el máximo interés aquí:

La universidad piensa (o pensaba) que, para ser educador, o pedagogo, o profesor (o, incluso, para ser investigador), hay que ser, por un tiempo, estudiante. Por eso la obligación de la universidad no es sólo tratar a los alumnos como futuros profesionales sino convertirlos, por un tiempo, en estudiantes. En la universidad, por ejemplo, no sólo se aprende a ser médico, sino que se estudia medicina. No sólo se aprende a ser filósofo, o antropólogo, o ingeniero, sino que se estudia filosofía, o antropología, o ingeniería. No sólo se aprende a ser educador, o pedagogo, o profesor, sino que se estudia educación. Y como estudiar tiene que ver con cuidar, con estar concernido, con considerar, con dedicarse a algo, con mirar algo repetida y atentamente, podríamos decir que una facultad de educación no es sólo una fábrica de profesionales sino también, y quizá sobre todo, un lugar donde la educación, sea eso lo que sea, se defina como se defina, es objeto de cuidado, de preocupación, de atención, de dedicación, de estudio (Larrosa y Rechia, 2018, pp. 166-167).

2. Se trata del III Seminário Internacional de Filosofia, Poética e Educação: Elogio do Estudo y del II Seminário Internacional Elogio da Escola: sobre o ofício do Professor, que tuvieron lugar entre el 14 y el 30 de septiembre de 2018, el primero en la Universidade Federal de Juiz de Fora (UFJF), en Juiz de Fora/MG, y el segundo en la Universidade do Estado de Santa Catarin (Florianópolis), ambos en Brasil. 
Estudiar y aprender, entonces, no son la misma cosa, y su diferencia no es de grado, sino de naturaleza. Para aclararlo, ampliemos un poco más el comentario de Maximiliano a través de un cierto "rescate etimológico" de ambos términos (Bordelois, 2017, p. 17).

La palabra "aprendizaje» (apprehendere) está compuesta por "ad-» (hacia) y "prendere» (atrapar); en francés deriva en "prendre». De "prendere» proviene la palabra "preso". "Apprehendere» quiere decir "agarrar" o "asir algo con la mano". Poco a poco la palabra va adquiriendo un sentido metafórico y empieza a significar "coger con la mente», "comprender», «abarcar», «abrazar» incluso (D'hoest, 2015). La palabra estudio (studium), significó "empeño", "aplicación", "celo", "ansia», "cuidado", "desvelo", "afán". Posee el sentido de "afecto" (sstudia habere alicuius" quería decir "gozar del afecto de alguien»). En su Didascalicon de studio legendi, Hugo de San Víctor dice que «la Filosofía es, en efecto, el amor, el afán y, en cierto modo, la amistad hacia la sabiduría" (San Víctor, 2011, p. 15). La palabra "estudiante» es un participio de presente del verbo «estudiar»: «el que estudia». En español — al contrario que en otras lenguas, en las que se forma directamente a partir del verbo latino studeo (en italiano, studente; en inglés, student, etc.) — , el participio se forma a partir del sustantivo "estudio", del latín studium, que viene, en última instancia, del verbo Studio, que en un principio significaba "dedicarse con atención (a algo)", "tener gran gusto (por algo)», "estar deseoso (de algo)», "realizar con afán», etc. Estudiar era poner el alma en algo que a uno le gustaba y hace libremente, lo cual no significa que no exija esfuerzo y trabajo, en el sentido de ejercicio, o sea, de disciplina. Precisamente el sustantivo "disciplina" viene del verbo "disceo", "aprender".

Por tanto, si en el aprender el acento está colocado en el sujeto que aprende como sugiere Maximiliano en la convocatoria que nos hizo-, en el estudio el énfasis está colocado en el objeto a ser estudiado. Se estudia en virtud de un encantamiento, de una fascinación, de una seducción, en función de una admiración que está más allá de cualquier utilidad prevista. Por eso, el estudio es una actividad libre, y en tal sentido, desinteresada. El estudio tiene en él mismo su propio fin (Reboul, 1980, p. 82). En el estudio, el sujeto es tomado, atrapado, capturado, seducido, agarrado por el objeto de estudio. Apunta, sobre todo, al deseo de colocarse en relación con algo, de cuidarlo y prestarle atención. De acuerdo con estas consideraciones, se entiende que el estudioso no se sirve de aquello que estudia, sino que, por el contrario, se desvive por ello, se disuelve en lo estudiado, le dedica su vida, la gasta y la empeña.

Estudiar tiene que ver con cuidar, se nos indica, y esto significa que tiene que ver con la atención y el repliegue sobre uno mismo. La cita anterior de Jorge Larrosa sitúa cualquier sosegada investigación sobre la actividad del estudio en las coordenadas contemporáneas en las que el estudio está siendo, como actividad, completamente banalizada en la actual universidad. Si el estudio se parece a la labor de Penélope, que hace y deshace su tela como un gesto que supone un acto de resistencia, hemos de preguntarnos ahora qué significa estudiar, entendida esa 
actividad como una forma de vida a la que el estudioso no puede dejar de dedicarse, porque ama lo que a diario hace con sumo afán.

\section{EL ESTUDIO COMO TIEMPO LIBRE}

El tiempo del estudio es un tiempo libre. La diferencia entre tiempo libre y tiempo esclavo se encuentra en el diálogo de Platón Teeteto, donde Platón consagra filosóficamente la Scholé (de donde proviene la palabra "escuela»). En un momento determinado, cuando la conversación parece haberse desviado de su rumbo inicial, Sócrates advierte a su interlocutor Teodoro que es mejor no seguir esa vía que se les ha abierto pues los llevaría muy lejos. Entonces, Teodoro, alarmado, pregunta: "¿Es que acaso no tenemos tiempo libre, Sócrates? Esta pregunta obliga al maestro a referirse al tiempo esclavo de los que rondan por tribunales y lugares semejantes, "que parecen haber sido educados como criados, si los comparas con hombres libres, educados en la filosofía y en esta clase de preocupaciones»(Platón, 1988, 172d). Esta clase de hombres disfrutan del tiempo libre, y sus discursos los componen en paz y en un tiempo definido por el ocio: no les preocupa nada la extensión de sus razonamientos, sino solamente alcanzar la verdad. Los otros, en cambio, son esclavos de un tiempo medido: no pueden hablar de lo que desean porque están bajo presión. Deben alcanzar determinados resultados, y por eso a menudo se buscan sus atajos, "se vuelen violentos y sagaces, y saben cómo adular a su señor con palabras y seducirlo con obras. Pero, a cambio, hacen mezquinas sus almas y pierden toda rectitud. La esclavitud que han sufrido desde jóvenes les ha arrebatado la grandeza del alma, así como la honestidad y la libertad» (173a). Esos jóvenes, dice Sócrates, "llegan a la madurez sin nada sano en el pensamiento» (173b). Podríamos decir entonces que bajo la modalidad de un tiempo esclavo y medido el individuo carece de "carácter» (pues no ha tenido tiempo suficiente para formarlo debidamente, incluso puede tenerlo corrompido), y por eso necesita que le señalen un método de antemano; en el tiempo de los hombres libres, en cambio, sencillamente no es necesario que prescriban de antemano método alguno, por la simple razón de que ahí siempre, y sin saber cómo, ya se está en camino, aunque uno se pierda con frecuencia en su recorrido. El tiempo del filósofo — que es el que lleva una forma de vida orientada por cierta clase de amor-, es el que se demora largo tiempo en un mismo asunto, el que sabe esperar y no pasa rápidamente de una actividad a otra. No parece que padezca del vicio de la stultitia, de la que habla Séneca en su famosa carta a Lucilio (Séneca, 2018, 52, pp. 266-271).

Ahora bien, ese tiempo es «libre" porque tales individuos pertenecen a un grupo en cierto modo "privilegiado", a una especie de aristocracia filosófica que se concede el poder dedicarse a los trabajos del espíritu al no tener que preocuparse de otras necesidades vitales mediante el trabajo o la labor (esto es lo que enoja, como vimos, a Bourdieu). Como el tiempo es de ocio, en realidad parece que lo que hacen es lo más parecido a una fiesta (incluso un juego, aunque muy «serio»), algo que tiene 
que ver con la relajación y la falta de esfuerzo (de esa clase de esfuerzo en que consiste trabajar o laborar). En el mundo totalitario del trabajo (de la producción) no hay lugar para la relajación, para ninguna clase de fiesta ni juegos, para un espacio inutilizado o inutilizable: en el trabajo, la fiesta es una especie de falso ocio, pues la relajación que en él se ofrece está destinada a reponer las fuerzas para seguir trabajando con ahínco al día siguiente (Pieper, 2017). Dedicarse, en consecuencia, a una actividad estudiosa, tiene el extraño carácter «del mero lujo intelectual, incluso de algo verdaderamente intolerable e injustificable» (Pieper, 2017, pp. 71-71). Lo que hace el estudioso no es un trabajo, y su actividad parece interminable. ¿Acaso dedicarse a una vida estudiosa no nos hace acreedores del calificativo de "Ociosos diletantes»? Podríamos preguntarnos, entonces, si en un contexto donde todo está organizado en torno al mundo totalitario del trabajo es posible ofrecer al sujeto un ámbito de actuación que no sea ya exclusivamente "trabajo" sino "ocio" (para que se ejercite en el tiempo de los hombres libres). Lo interesante del asunto consiste en disponerlo como ocio.

Así pues, me encontraba yo, hace meses, pensando en estas cosas, y me obligaba a poner, como lector y como profesor, al lado de lo que estaba haciendo este otro decorado, mientras seguía ensalzando mi particular elogio de la lectura; mientras leía con mis estudiantes en el aula textos antiguos en voz alta y les obligaba a detenerse en cada frase; mientras les forzaba a escribir cada día en sus diarios filosóficos y les forzaba a que leyesen de nuevo la cita, el fragmento o el texto que ya habíamos considerado en una sesión anterior. En fin, que mientras hacía todo esto también sentía que estaba recitando, pongamos por caso, "La vida es sueño" mientras unos anónimos espectadores reían de buena gana al observar que detrás de mí, y sin yo apenas notarlo, el decorado estaba cambiando, no tendiendo ya nada que ver con lo que yo estaba declamando. A pesar de todo, había una cierta clase de insistencia o de terquedad en mí, una especie de no querer ceder a determinadas presiones. Un día, por casualidad, cayó en mis manos una antología de escritos de Maquiavelo donde encontré una carta (10 de diciembre de 1513), dirigida a su amigo Francesco Vettori. Le describe su día y, en un momento determinado, dice:

Llegada la noche, me vuelvo a casa y entro en mi escritorio; en el umbral me quito la ropa de cada día, llena de barro y de lodo, y me pongo paños reales y curiales. Vestido decentemente entro en las antiguas cortes de los antiguos hombres, donde - recibido por ellos amistosamente- me nutro con aquel alimento que sólo (solum) es mío y para el cual nací: no me avergüenzo de hablar con ellos y de preguntarles por la razón de sus acciones, y ellos con su humanidad me responden; durante cuatro horas no siento pesar alguno, me olvido de toda preocupación, no temo a la pobreza, no me da miedo la muerte: me transfiero enteramente en ellos (Maquiavelo, 2009, p. 396).

No pude sino asentir a lo que esta epístola me estaba diciendo y, casi de memoria, se la recitaba a mis estudiantes queriéndoles convencer de las verdades que la misma contenía. Pero, claro está, en realidad se trataba de «mi verdad», no 
de la suya. Me repetía a menudo que el centro de todo en mi vida como profesor de universidad es la transmisión, el encuentro con los estudiantes y el aula. Pero también me recordaba que, en realidad, ese momento comienza mucho antes; pues se prepara en el cuarto de estudio o en la biblioteca. Se anticipa en un régimen de vida, en determinados hábitos y pequeños rituales que convocan la lectura y la escritura, en la preparación de las clases, en la elección de las lecturas y los motivos, en la historia que, en mi caso, cada año quiero contar a mis estudiantes de filosofía de la educación. Me pregunto si en esos hábitos y rituales hay una especie de cuidado de sí que se orienta al cuidado de ese otro momento del aula.

El profesor (que estudia) lo que busca es dar a estudiar a sus alumnos, que con este gesto espera se tornen estudiantes y salgan por fin de su condición de alumnos (Larrosa y Rechia, 2018, p. 166). El profesor considera que hay cosas importantes que deben transmitirse, y adquiere la responsabilidad de enseñarlas en su materia, que dispone como un objeto de estudio. Y con ese gesto, como señalan Simons y Masschelein (2014), libera su materia de su uso habitual posterior, provocando que se tornen públicas, presentes en el mundo, compartidas, dignas de estudio. Este es, sin más, el propósito de ese espacio llamado escuela: un lugar destinado a convertir algo en objeto de estudio (mediante la atención, para promover el conocimiento por amor al conocimiento), y en objeto de práctica (promoviendo la habilidad por amor a la habilidad).

\section{EL ESTUDIO COMO EJERCICIO: LA LARGA FATIGA}

Estudiar es una forma de ejercitación que supone una larga fatiga. Veamos en qué sentido. En algunas epístolas de Horacio encontramos algunas meditaciones sobre la vida del pensamiento, la escritura y el estudio como un êthos en las que se nos muestra un tipo humano que tiene un gusto predominante por la cultura de las letras y el goce estudioso. Horacio presenta al estudioso en sus difíciles relaciones sociales con los otros, en sus egocéntricas demandas sobre la realidad, en sus exigencias de confort doméstico, sus necesidades afectivas y en parte elitistas de amistad, en fin, un tipo humano por entero inmerso en la cultura libresca. En una de esas epístolas, explica que "así pues, ahora dejo versos y demás diversiones. Sólo me interesa la verdad y la moral. Reúno y almaceno para más tarde poderme abastecer» (Horacio, 2016, I,1, p. 10). Y en otra, dirigida a un tal Lolio Máximo, comenta, en tono irónico, pero severo: «Para degollar a alguien se levantan de noche los bandidos. Para servirte a ti mismo, ¿no te despiertas? Mira que, si no te quieres sano, correrás con hidropesía; y si no pides libro y lámpara antes de amanecer, si no diriges tu ánimo a estudios y codas honestas, insomne la envidia o el deseo te atormentarán» (Horacio, 2016, I, 2, pp. 35-40).

De igual manera, el filósofo Francis Bacon se refiere al êthos del conocimiento en su ensayo "Del estudio", que forma parte de sus Ensayos sobre moral y política, donde asigna a la lectura un papel principal en una vida estudiosa. Bacon ofrece 
principios generales, pero precisos, sobre los propósitos de toda lectura. Tales consejos son, indiscutiblemente, una herencia de la antigüedad filosófica, dentro de la cual la lectura formaba parte de un buen arte de vivir:

No leas para contradecir y refutar, ni para creer y dar por sentado, ni para hallar charla y discurso, sino para sopesar y meditar. Algunos libros merecen ser saboreados, otros ser devorados, y unos pocos ser masticados y digeridos; es decir, algunos libros son para leer sólo por partes, otros para leer sin concentración excesiva, y unos pocos para leer por completo, y con diligencia y atención. [...] La lectura hace un hombre completo, la conversación un hombre dispuesto, y la escritura un hombre preciso (Bacon, 1999, p. 190).

Estas y otras imágenes del estudioso son bastante conocidas. Hay dos de ellas que me interesa destacar ahora, y que quizá lo sean menos. La primera es de Comenius, y figura en Orbis sensualium pictus: «El estudio es el lugar donde el estudioso, separado de los demás, se sienta en soledad entregado a su afición mientras lee los libros, que abre sobre un atril cerca de él, y de ellos va tomando en su libreta lo mejor o en ellos hace anotaciones o señala al margen con un asterisco» (Comenius, 2018, p. 2015). La separación del mundo, la lectura y los libros, la libreta y las anotaciones son elementos que se mantienen en esta descripción de una obra del año 1658. La otra (de 1593), pertenece a la Iconología de Ripa (1996):

Joven de pálido rostro vestido con modesto atuendo. Estará sentado sosteniendo un libro abierto con la siniestra, mirándolo atentamente, mientras con la diestra sujeta una pluma en actitud de escribir. A su lado se ha de poner un gallo y una luz encendida. Se pinta joven porque en dicha edad se suele ser más apto y resistente para las fatigas del estudio. Aparece pálido porque los estudios suelen extenuar y agotar el cuerpo [...] Viste ropas modestas, porque los estudiosos suelen atender con exclusividad a las cosas moderadas y sencillas. Y se pinta sentado, mostrando la quietud y asiduidad que el estudio requiere. La atención fija y volcada sobre el libro abierto, muestra cómo el estudio no consiste sino en una vehemente aplicación del ánimo al conocimiento de las cosas. La pluma que sostiene significa la operación y la intención que cuando se escribe se manifiesta de dejar memoria de sí mismo. La luz que mantiene encendida muestra que los estudios consumen más aceite que vino, Y en cuanto al gallo, muchos lo ponen por su solicitud y vigilancia, siendo ambas cosas convenientes y necesarias si de estudiar se trata (pp. 386-87).

La palidez del estudiante y la modestia de su vestimenta — símbolos de un alejamiento de las cosas del mundo-, su fatiga por el mucho estudiar, son expresiones de cierto ánimo melancólico y de un esfuerzo incesante. ¿Qué permite a un individuo dotarse de la fuerza necesaria para entregarse con tanta dedicación a una actividad de escritura, lectura y estudio? ¿Qué sostiene la realización de un proyecto que exige el abandono de casi toda convención social y la decisión en favor de un exilio autoelegido? Marcel, el narrador de En busca del tiempo perdido, quiere escribir una novela, pero no cree en sus talentos literarios para poder componerla. Hacia el final del largo periplo narrativo, se topará con la revelación definitiva que 
concederá el impulso definitivo. Es entonces cuando experimentará una necesidad de retirada: «Tenía la sensación de que el desencadenamiento de la vida intelectual era bastante intenso en mí en aquel momento para continuar tanto en el salón, en medio de los invitados, como a solas en la bibliotecan (Proust, 2003, p. 274). El narrador sabe ya que ha de ponerse a escribir su libro, y al mismo tiempo no tiene dudas del tremendo esfuerzo que supondrá su tarea: «iQué tarea tendría por delante!», señala (Proust, 2003, p. 409). Y añade:

Para dar una idea de ella, habría que recurrir a las comparaciones con las artes más elevadas y más diferentes [...] [S]oportarlo como una fatiga, aceptarlo como una regla, construirlo como una iglesia, seguirlo como un régimen, vencerlo como un obstáculo, conquistarlo como una amistad, sobrealimentarlo como a un niño, crearlo como un mundo (p. 410).

Estas imágenes son prodigiosas: soportar, aceptar, conquistar, alimentar, crear... amistad. Realmente se trata de un auténtico trabajo de áskesis, a la vez de renuncia (al mundo social) y de ejercitación (en la escritura). Hugo de San Víctor recoge, en el siglo XII, la tradición griega que citaba al inicio de este ensayo en su Didascalicon, citando explícitamente el "conócete a ti mismo" (gnoti seauton) que recorrerá toda la tradición antigua. Leer era, en el seno esta tradición, un verdadero trabajo del espíritu en el que el lector se libera de las preocupaciones cotidianas y se repliega sobre sí -leyendo tan deliberadamente como el libro fue compuesto-, meditando con serenidad y obligándose a permitir que los textos hablen por y desde ellos mismos. Lo que Hugo pide al lector, como escribe Illich, es «que se exponga a la luz que emana de la página [...] de tal modo que pueda identificarse a sí mismo, reconocer su yom (Illich, 2002, p. 33).

Las prácticas del estudio (leer, escribir, pensar, escuchar), según estas referencias, constituyen un "ejercicio espiritual». El término "ejercicio" (exercitium) significa la «acción de ejercer algo sobre alguna cosa» o de «formarse a sí mismo» (Diccionario Littré 1960, p. 660). El término viene asociado a las nociones de trabajo y entrenamiento. El verbo «ejercer" connota, sobre todo, aspectos vinculados con la repetición, la gimnástica y la práctica. El término «espiritual» es más complejo. Tiene un aspecto teológico y religioso, pero a nosotros nos interesa destacar otro sentido: la preocupación por la vida interior e íntima, su componente de experiencia subjetiva, una experiencia que está fuera de cualquier forma de organización religiosa o eclesial, por así decir. Es el trabajo del alma sobre sí misma, un ejercicio que busca la sabiduría con el objeto de vivir lo mejor posible una vida humana en tanto que humana (Pavie, 2012, p. 20).

En la correspondencia de Gustave Flaubert encontramos una carta dirigida a su amiga Marie-Sophie Leroyer de Chantepie (del 18 de mayo de 1857) que nos ofrece una interesantísima reflexión. La amiga de Flaubert se lamenta del estado del mundo, y anhela mejorar y cambiar las cosas, y éste le dice: «Se rebela usted contra las injusticias del mundo, contra su bajeza, su tiranía y contra toda la infamia y fetidez 
de la existencia. ¿Las conoce bien? ¿Lo ha estudiado todo? ¿Es usted Dios?» (Flaubert, 2009, p. 106). Flaubert le prescribe, su propia receta, haciéndole notar que, como ella quizá carece del hábito de la contemplación, tal vez fuese conveniente ponerse a estudiar: "Tómese la vida, las pasiones y a usted misma como un motivo para el ejercicio intelectual", le dice (Flaubert, 2009, pp. 106-107). Si queremos vivir, "hay que renunciar a tener una idea tan clara de todo. La bumanidad es así, no se trata de cambiarla, sino de conocerla. No piense tanto en usted. Abandone la esperanza de una solución» (Flaubert, 2009, pp. 106-107). Flaubert anima a su amiga a poner en práctica un régimen de estudio:

[...] En el ardor del estudio hay alegrías a la medida de las almas nobles. A través del pensamiento, únase a sus hermanos de hace tres mil años; recoja todos sus sufrimientos, todos sus sueños, y sentirá cómo se ensanchan, al mismo tiempo, el corazón y la inteligencia [...] Haga grandes lecturas. Adopte un plan de estudios que sea riguroso y sostenido [...] Impóngase un trabajo regular y fatigoso. Lea a los grandes maestros y trate de captar su conducta, de acercarse a su alma. De ese estudio saldrá deslumbrada y alegre (p.107).

Le dice, en fin, que se atreva a la contemplación, al pensamiento, a la vida intelectual. Le sugiere que es mejor conocer el mundo que pretender cambiarlo, y le hace notar que ese estudio es un cierto ejercicio intelectual, o sea, un cierto ejercicio «espiritual»: una forma de vida, pues.

Pero todo ello requiere de un aislamiento. Tal aislamiento hace del estudioso un miembro de la tribu de los melancólicos - la melancolía es una pena que no tiene nombre, decía Joseph Joubert (2009, p.304). El melancólico forma parte de los intelectuales que hacen de la desdicha por el estado del mundo el fundamento de su existencia, como dice Wolf Lepenies: «Está crónicamente insatisfecho; sufre por el estado del mundo. La queja es su oficio [...] Sólo puede reflexionar y no actuar» (Lepenies, 2007, p. 28). El melancólico se halla un poco al margen de las leyes habituales de la vida (Földényi, 1986, p. 20; Starobinski, 2012, p. 26). Es el estudioso, entonces, un melancólico que pertenece a una especie caracterizada por una insaciable sed de reflexión y meditación, quedando atrapado en su interior. Pareciera, pues, que es un insatisfecho crónico que, cuanto más lee y medita o reflexiona, más extraño se encuentra dentro del mundo (Clair, 2006, p.203). Al dolerle el mundo que habita busca un modo de expresión, y con frecuencia dicha expresión es algo que tiene que ver con la creación. Anhela crear, para dar salida a sus inspiraciones, y necesita volver, una y otra vez, a ese estado de melancolía, que, así piensa, le permitirá seguir creando.

Exploremos a continuación, con algo más de detalle, la noción de forma de vida aplicada al estudio. Agamben anota que una forma de vida que tenga relación con una práctica "poética" (lo poético hace referencia al acto de creación o tornar algo visible en el mundo, es un acto de poíesis), está siempre en el estudio, está siempre en $s u$ estudio: en un gabinete o "cuarto de estudio» que se habita y en un "ponerse 
a estudiar»). Tanto el espacio donde se estudia (o donde se pinta) como la actividad misma del estudiar (o pintar) no parecen siempre ordenados, sino revueltos: «En el desorden de las hojas y de los libros abiertos o amontonados uno sobre el otro, en las posiciones desordenadas de los lápices, de los colores y de las telas colgadas en la pared, el estudio conserva el testimonio de la creación, registra las huellas del laborioso proceso que conduce de la potencia al acto, de la mano que escribe a la hoja escrita, de la paleta a la tela» (Agamben, 2018, p. 13).

Agamben destaca que el estudio es la imagen misma de la potencia (el poder de hacer y el poder de no hacer):

La potencia de escribir para el escritor, de la potencia de pintar o esculpir para el pintor o el escultor. Intentar la descripción del propio estudio significa entonces intentar la descripción de los modos y las formas de la propia potencia, una tarea, al menos a primera vista, imposible (p. 13).

Propiamente hablando, esa potencia no se tiene, del mismo modo que se posee una destreza o habilidad técnica, sino que se habita: "Habitar es un modo especial del tener, un tener tan intenso como para no poseer nada más. A fuerza de tener algo, lo habitamos, nos volvemos suyos" (Agamben, 2018, p. 13). El estudio, pues, es la forma de un habitar, dentro de un interior (erigiendo una intimidad). Ahora bien, sólo se habita bien algo, y se lo conoce, si se lo ama suficientemente. La raíz indoeuropea de "conocer", recuerda Agamben, es homónima de la que significa "nacer": "Conocer significa nacer juntos, ser generado o regenerado por la cosa conocida. Y esto y no otra cosa significa amar» (Agamben, 2018, p. 14). "Conocer» es «co-nacer» (en francés, por una suerte de azar lingüístico, connaître es co-naître): "Es bueno quitarle al verbo "conocer» toda pretensión meramente cognitiva (cognitio [conocer] en latín es en origen un término jurídico, que designa el procedimiento de requisitoria de un juez)» (Agamben, 2018, p. 14). El saber siempre es hijo de una gran pasión amorosa.

Vemos que el estudio impone un estilo de vida. Es una forma de vida concentrada en mirar, escuchar, pensar, escribir, leer: "Hacer algo consigo mismo, hacer algo con otros, ser afectado por el mundo de una cierta manera" (Tatián, 2017, p. 82). Es una condición existencial. Hace falta tener mucho afán, y mucho amor, para sostenerse en tal actividad: "Para pensar no hace falta nada. Para estudiar sí" (Tatián, 2017, p. 83). Se necesitan condiciones materiales: un lugar para estudiar, unos libros que leer, ciertos cuadernos donde escribir; pero también condiciones temporales: disponer de un tiempo liberado de las exigencias del trabajo y la labor para poder emplear la vida en el estudio. Se precisan, en fin, ciertas condiciones internas: querer hacerlo, tener deseo de estudiar. Por eso lo que resulta en verdad irritante es que las casas del estudio de hoy (y estoy pensando en las universidades) sean las que más obstaculizan la actividad del estudio y la disponibilidad de un tiempo para fomentar el afán por esta actividad. 
El estudio posee, en definitiva, un carácter interminable; tanto, que produce una larga fatiga. El estudioso no ve, en el horizonte, el final de lo que hace. Es un medio sin fin predeterminado:

El estudio es, de hecho, en sí interminable. Cualquiera que haya vivido las largas horas de vagabundeo entre los libros, cuando cada fragmento, cada código, cada inicial con la que se topa parece abrir un nuevo camino, que se pierde de repente tras un nuevo encuentro, o haya probado la laberíntica ilusión de la "ley del buen vecino", que Aby Warburg había establecido en su biblioteca, sabe que el estudio no sólo no puede tener propiamente fin, sino que tampoco desea tenerlo. Aquí la etimología del término Studium se hace transparente. Se remonta a una raíz $s t$ - o $s p$ - que indica los choques, los shocks. Estudiar y asombrar son, es este sentido, parientes: quien estudia se encuentra en las condiciones de aquel que ha recibido un golpe y permanece estupefacto frente a lo que le ha golpeado sin ser capaz de reaccionar, y al mismo tiempo impotente para separarse de él. Por lo tanto, el estudioso es al mismo tiempo también un estúpido (Agamben, 1989, p. 46).

No tiene fin el estudio y "no desea tenerlo". De ahí la fatiga que el estudio impone. En su carácter interminable, el estudio asombra al estudioso, hasta volverle "estúpido». Hay una suerte de alternancia, en el estudio, de sufrimiento, pasión y terca continuidad. Ahí reside el "ritmo» propio del estudio:

[S]i por un lado permanece tan atónito y absorto, si el estudio es pues esencialmente sufrimiento y pasión, por el otro [...] lo empuja hacia la conclusión [...] Este alternarse de estupor y lucidez, de descubrimiento y de turbación, de pasión y de acción es el ritmo del estudio (Agamben, 1989, pp. 46-47).

De acuerdo con esta descripción, el estudio siempre se demora en una potencia no del todo actualizada, e impone una larga paciencia. No sabe, el estudioso, cuál es su propósito, y hacia dónde le encaminan sus pasos. Cuando lee y estudia, el poeta latino Horacio dice en una de sus epístolas que «adonde los vientos me arrastran me dejo llevar» (Horacio, 2016, I, 1, p.15). No extraña la tristeza del estudioso, pues "nada es más amargo que una prolongada demora de la potencia» (Agamben, 1989, p. 47). El fin del estudio jamás se alcanza.

Como actividad, el estudio es una "práctica» (praxis, pero también poíesis), un poco en el sentido en que consideró este concepto Alasdair MacIntyre en After Virtue, una noción que "comprende las investigaciones de la física, la química, y la biología, el trabajo del historiador, la pintura y la música» (MacIntyre, 1987, p. 236). En estos y otros campos, sus ejercitantes se dedican de lleno a sus actividades con una especie de ánimo estudioso. Si bien cada una de estas prácticas están cobijadas en instituciones mayores que persiguen sus propios fines (ejemplaridad social, prestigio, poder, dinero), tales fines no tienen por qué coincidir con los fines o bienes de las prácticas que cobijan, que no son externos, sino internos a las mismas actividades realizadas. Pues es participando de determinada manera en dichas 
actividades como sus ejercitantes alcanzan el bien de cierta clase de vida: «Esa vida puede que no constituya toda la vida para el pintor que lo es desde hace mucho, o puede serlo durante un período, absorbiéndole como a Gauguin, a expensas de casi todo lo demás» (MacIntyre, 1987, p. 236). Pero el asunto es que, como en este caso - en el que el pintor vive como pintor-, el estudioso, al ejercitar su actividad de determinada forma, vive su vida en tanto que estudioso (a veces también a expensas de todo lo demás, y sosteniéndose en su larga fatiga).

\section{EL EXILIO ESTUdIOSO. UNA REFLEXIÓN SOBRE EL CUADERNO DE NOTAS}

El estudioso, hemos dicho, necesita apartarse de los ritmos habituales del mundo. El gabinete de estudio es el lugar en el que la persona volcada al conocimiento abandona, quizá, su máscara de insignificancia para ser, por fin, ella misma. Judith Schlager (1997) formula este pensamiento de la siguiente manera:

Es el lugar de su soledad, de sus intereses y de sus pasiones, y es allí donde su retirada se formula como un orden aparte. Es allí donde se despliega la lógica del mundo estudioso, una lógica consciente que se desarrolla a distancia del mundo exterior y que está fuera del alcance de su mirada. La frase de Goethe —-donde comienza la vida intelectual, se detiene la política- proclama bien el principio de esta independencia. Seguramente, la retirada estudiosa supone la política y exige el mundo, y el gabinete de trabajo es menos autónomo de lo que se cree. Más aún, esta estancia no es sabia y no le vuelve más sabio a uno. Pero es un régimen de trabajo donde se desliza una vida, iluminada por su sorprendente vocación (p. 220).

El estudioso, recluido en su cuarto de estudio o en la biblioteca, se entrega a su tarea como un lector lo hace a la lectura o un escritor a la escritura de su novela. El estudioso experimenta un encierro. Al final de su periplo, el narrador proustiano también debe exiliarse:

Lo que yo debía escribir era otra cosa, más larga y para más de una persona: larga de escribir. De día, lo más que podría intentar sería dormir. Si trabajaba, no sería sino de noche, pero necesitaría muchas noches, tal vez cien, tal vez mil, y viviría con la ansiedad de no saber si el dueño de mi destino, menos indulgente que el sultán Sheriar, por la mañana, cuando interrumpiera mi relato, tendría a bien aplazar mi condena a muerte y me permitiría proseguir la noche siguiente (Proust, 1989, IV, p. 620).

En el siglo XIV, Petrarca le escribe una carta al dominico Giovanni Colonna y le dice: "Sólo en la soledad soy dueño de mí mismo y no en otra parte: en ella mi pluma (calamus) es verdaderamente mía y no en otra parte». El estudioso, por tanto, requiere soledad. Ahora recuerdo lo que un profesor de historia de la educación nos decía en sus clases: "El estudio es libertad y soledad». Rafael Sánchez Ferlosio, tras escribir su novela El Jarama, entre octubre de 1954 y marzo de 1955, "agarra" (la expresión es del propio Ferlosio, en "La forja de un plumífero») la Teoría del 
lenguaje, de Karl Bühler y se sumerge en la gramática y la anfetamina. Sin apenas salir de casa, exiliado y asocial. Y así se pasa estudiando 15 años. Ivan Illich señala que «el lector es alguien que se ha hecho a sí mismo dentro de un exilio para poder concentrar toda su atención y deseo en la sabiduría, que se convierte así en el hogar anhelado" (Illich, 2002, p. 27). El estudioso es un peregrino del espíritu (peregrinatio in stabilitate). Como también dice Barthes, "para tener tiempo de escribir, es necesario luchar a muerte contra los enemigos que amenazan ese tiempo, hay que arrancarle ese tiempo al mundo, a la vez por una elección decisiva y por una vigilancia incesante» (Barthes, 2005, p. 267). Como de pasada, Barthes anota — para hacer de la propia vida una obra- que la solución es la escritura de un diario, que obliga a escribir casi cada día. El mundo y la obra son rivales; el mundo y el estudio son enemigos. Si no podemos cambiar el mundo, lo mejor es tratar de comprenderlo, estudiándolo.

Imagino una jornada de un estudioso. Le observo leyendo sentado o mientras camina y, a cada rato, tomando notas de lo que piensa, de lo que observa, de lo que lee o ha leído. ¿Tiene que llevar el estudioso un cuaderno de notas? ¿Por qué ha de hacerlo? ¿Qué clase de cuadernos? Jean Guitton se pregunta en El trabajo intelectual: «Cómo recoger con signos el trabajo de la mente, cómo fijar el pensamiento de los demás y el nuestro, para que podamos volver a pensar, revisar y practicar, sobre lo que hemos conocido y amado una vez, este movimiento de retorno que es el conocimiento?» (Guitton, 2010, pp. 95-96). En su breve ensayo, Guitton comenta que es en verdad una feliz costumbre llevar un diario que nunca será desvelado, un cuaderno en el que escribir solamente para uno mismo. Cada uno puede sacar provecho de esa práctica, que es antiquísima. Para quienes se inician en la vida del estudio es realmente aconsejable esa práctica en la que preparan en secreto este humus del saber.

¿De qué sirven los cuadernos? Releerlos, tras haberlos largo tiempo olvidado, constituye una auténtica celebración del recuerdo. Emerson, firmando bajo pseudónimo (Junio) una entrada de su Diario, el 15 de enero de 1820, escribe: «Mezclar los miles de anhelos y pasiones y objetos del mundo personificados por la Imaginación es provechoso y entretenido. Estas páginas tratan de contener en su comienzo un registro de nuevos pensamientos (cuando convengan), como un receptáculo de todas las viejas ideas que una ojeada parcial y peculiar a la antigüedad pueda proporcionar o renovar, como un cuaderno para salvar el desgaste de la débil Memoria» (Emerson, 2015, p. 21)

Si escribir un Diario personal nos resulta pudoroso, y a menudo, tras escribirlo, nos avergonzamos de lo que allí escribimos, llevar un cuaderno de notas es otra cosa bien diferente. Estando nosotros en ellos, no lo estamos tanto o no del todo. En ellos recogemos lo que hay en el mundo y en los libros. Esos cuadernos nos ayudan a centrar nuestra atención en lo esencial de un asunto. A mí, escribir en mis cuadernos me ayuda a pensar. Constantemente escribo en ellos — cuando estoy 
enfrascado en un asunto-, las mismas ideas y, al reescribirlas una y otra vez, no sólo las fijo, sino que me aclaro yo en ellas. Del mismo modo, escribir nos propone ciertos límites, impidiéndonos que queramos hablar después de todo. Escribir en cuadernos, por fin, nos calma, nos alivia, nos descarga, pues de algún modo nos ayuda a expresar lo que parecía inexpresable.

La operación de escribir en cuadernos, como la de leer en papel, y no en formato electrónico, es una operación de resistencia en un mundo hipertecnologizado. No es la misma operación la de escribir a mano que teclear, como no es igual leer en papel en vez de en una pantalla. En la escritura a mano uno se obliga a constantes detenciones del pensamiento. Hay que tomar decisiones adecuadas: ¿Qué es lo que debo anotar aquí? ¿Qué merece la pena ser conservado? ¿Qué fragmento de esta u otra obra convertir en cita, para una lectura posterior? No es necesario haber pasado por la universidad para hacer este tipo de cosas. Se trata, sin duda, de un determinado arte de vivir que pasa por la escritura y, por ende, por lo literario. El cuaderno que llevamos con nosotros, en un mundo acelerado como el nuestro, es una oportunidad para quedarse atentos, parados y pensando en lo que vemos. Escribir a mano obliga a quedarse quietos y en silencio. Nietzsche escribió muchos de ellos: cuadernos pequeños y manejables (que usaba para distintos libros), donde el apunte aforístico fuese posible. La práctica de anotaciones en cuadernos tiene que ver, por cierto, con un motivo tan nietzscheano como es la voluntad contra el sistema; para el filósofo, la voluntad de sistema era una falta de honradez intelectual.

Paul Valéry acumuló centenares de cuadernillos, donde leemos este tipo de cosas: "Alegría - emoción de levantarse a la 5 de la mañana y ponerse a anotar un montón de ideas, se diría, simultáneas, experimentando una extrema rapidez íntima» (Valéry, 2017, p. 32). ¿Qué hay que escribir en esos cuadernos? De nuevo, Valéry: "En estos cuadernos no escribo mis "opiniones", sino que escribo mis formaciones» (Valéry, 2017, p. 31). Es una buena pista. El estudio, calma, y excita al mismo tiempo. A veces no nos deja dormir. Hay una experiencia muy particular en la vida estudiosa, en el estudio considerado como una forma de vida, como un ejercicio, como una de las bellas artes. ¿Se la puede considerar así?

En sus cuadernos, Valéry ejercita la "musculatura» de su pensamiento. Esta es la razón principal que le mueve a levantarse entre las cuatro y cinco de la mañana, con estoica disciplina, para ponerse a escribir en sus libretas, hasta enviciarse con ellas completamente. No lo hace por escribir libros. Lo que hace es su propia mente: la conforma. Y se transforma en un "vicio». Su trabajo en esos cuadernos es el trabajo de Penélope: "Mi trabajo es de Penélope, este trabajo en estos cuadernos»; o esto otro: "En suma - esto (estos cuadernos de apuntes) son pilas de estudios para some 'philosophy' (whose name I dislike- or a Miso-sophys (Valéry, 2017, p. 33). Se trata, dice, de «los tanteos de la mañana» (Valéry, 2017, p. 34). Valéry escribe sus anotaciones porque está convencido de la «naturaleza provisional, perpetuamente provisional, de todo lo que me viene a la mente» (Valéry, 2017, p. 35). Lo 
que escribe, lo escribe para él mismo — "no lo escribo sino para mí" (Valéry, 2017, p. 35); o, dicho de otro modo: "Diario de mí» (Valéry, 2017, p. 37). Es el momento de la rotunda soledad, de la imparable mismidad, de la complacencia en la falta de semejanza con los otros: "A esta hora, las 5 de la mañana, me repugna ser obligado a trabajar con la mente pensando en la opinión de otro. Es la hora de ser lo menos semejante, lo más único posible» (Valéry, 2017, p. 35).

El estudioso, como el escritor, no está encerrado todo el tiempo en su cuarto de trabajo. También se pasea. El paseo forma parte de su trabajo como estudioso o como escritor. Camina y deambula o callejea porque quiere que los dedos de sus pies piensen, porque está convencido de que las mejores ideas son una especie de pieza de caza, que hay que tomar al vuelo. No sabe, en realidad, qué está buscando: lo sabrá cuando se lo encuentre. Y por la tarde, o por la noche, entonces sí, encerrado en su gabinete, escribirá en su cuaderno de notas. Ese cuaderno, que quizá haya llevado consigo en su paseo matinal, es un lugar intermedio entre la blancura de la página y el libro ya compuesto. Los cuadernos de notas de Nietzsche dan cuenta de su naturaleza como escritor y son un ejercicio preparatorio. Son la patria del estudioso y del escritor, su hogar verdadero, su último refugio y libertad. No somos escritores por haber escrito libros, sino por haberlo intentado emborronando cuadernos de notas. Como dice Miguel Morey en su breve ensayo "Cuaderno de notas»: "Podría decirse que el escritor comienza a ser escritor a partir del momento en el que se ve emplazado ante la amenaza de la imposibilidad de la obra: se reconoce como escritor en el riesgo de no poder comenzar la obra (Kafka) o de no poder conducirla (Proust)» (Morey, 2007, pp. 355-356). En su curso sobre la novela, Barthes también es muy concreto: «El cuaderno, no demasiado grande», dice; y refiere los cuadernos oblongos de Flaubert, «en bello molesquín negro», y los de Proust; menciona incluso un tipo de «bolígrafo con resorte (rapidez: no tener sacarle el capuchón) (Barthes, 2005, p. 142). Para hacer un buen uso de este ejercicio del cuaderno de notas, hay que tener tiempo, estar libre. Una vez nos hemos habituado a esta práctica, desatenderla tiene sus efectos: "Cuando estoy cierto tiempo sin anotar, sin sacar mi cuaderno, tengo un sentimiento de frustración, de sequedad; volver a la Notatio: como una droga, un refugio, un resguardo. Notatio: como una maternidad [...] la interioridad como lugar seguro» (Barthes, 2005, p. 143).

\section{A MODO DE CONCLUSIÓN: DAR A ESTUDIAR}

Hemos hablado de los estudiosos, seres, muchas veces, intratables y asociales, a menudo huraños o cascarrabias incrustados en los márgenes de los siglos; lectores compulsivos y coleccionadores de libros raros, desconocidos para la mayoría; seres inactuales cuyas existencias se ordenan en torno a los libros que leen y la biblioteca que habitan; lectores que han sacrificado sus vidas por los libros para hacerlos entender y tornar comprensible la palabra a los otros. 
Con frecuencia, aunque no en todos los casos, estas gentes permiten la continuidad de la transmisión entre las generaciones y, por tanto, contribuyen a hacer posible la cultura. Aunque viven en el pasado - allí encuentran su alimento nutricio- aspiran a instalar lo mejor de sus pesquisas en el presente, para que otros logren pensar mejor y de otra manera y, quizá, incluso conmoverse: gesto de lo más revolucionario ese remplazo de lo inexistente (el pasado) por lo existente (el presente). Los estudiosos, alimentándose de los libros que leen, al mismo modo que tratan de expresar lo real de otra forma se distancian de una realidad ya previamente construida, precisamente para comprenderla más cabalmente.

He intentado un elogio del estudio como forma de vida, y lo que he querido decir con ello es que responde a una determinada vocación que compone un êthos: una actitud y una disposición del ánimo que forma un carácter. Una de las imágenes que me han guiado, el gesto de Penélope tejiendo y destejiendo su tela, sirvió para poner el énfasis en la audacia del gesto de resistencia que propone. Como Penélope, que resiste el acoso de sus pretendientes rehaciendo su tela constantemente, en el gesto de encerrarnos a estudiar resistimos el acoso de las formas banalizadas que se nos proponen abi afuera, cuando todo tiene que ver con una forma insignificante de lo que significa ponerse a aprender algo.

El estudio, se ha sugerido, es una actividad que impone un estilo de vida, determinados hábitos y maneras; una actividad que obliga a sostenernos en una larga fatiga, porque el estudio es una actividad improductiva, y no tiene que ser social o económicamente útil. Pero el estudio es, también, un espacio que se habita y donde uno se exilia. En ese espacio, el estudioso se ejercita en la lectura y la escritura de anotaciones. Me ha interesado hablar del estudio como espacio en su absoluta materialidad, precisamente porque solamente en un espacio así es posible mantener la quietud, la soledad, el silencio, y la repetición de gestos que toda buena lectura y escritura parecen demandar.

Recluirse para estudiar es un verdadero gesto de resistencia en una época en la que la escritura y el pensamiento están siendo sometidos a un proceso de estandarización que vuelven dichas actividades algo completamente superfluo. Cuando un estudiante de una Facultad de Educación te dice, casi avergonzado, que en sus estudios apenas le han recomendado sus profesores tres o cuatro libros intelectualmente interesantes, algo está pasando que debería darnos a pensar. Cuando una profesora o un profesor te dicen que sólo tienen tiempo para estudiar, y no para ponerse a publicar cualquier cosa, sometiéndose a las absurdas e incompresibles prescripciones que ordenan los organismos ministeriales de evaluación de la calidad educativa, también algo está pasando. Cuando ya no se puede ni entrar en la institución a la que uno le ha dedicado una parte importantísima de su vida sin sentir vergüenza ajena debido al tipo de conversaciones que a veces se escuchan (y no estoy diciendo que haya que estar hablando de Platón todo el tiempo), algo está pasando. 
Estudiar con cierta atención y cuidado, con amor y dedicación, con modestia y grandes dosis de humildad lo que deseamos transmitir después en el aula, hace que muchas cosas maduren en nosotros. Además, es un magnífico antídoto para dejar de pensar en nosotros mismos, de acuerdo con un ego - como el que ahora prolifera por doquier - hipersensible y al que todo le molesta y que, también en muchos «intelectuales», lo único que desea es lucirse. Y también es un buen remedio para no dar patinazos, cuando uno pretende hablar de lo que no ha estudiado con detenimiento.

Hay una cita de Petrarca, perteneciente a De sui ipsius et multorum ignorantia ("Sobre la propia ignorancia y la de muchos otros»), de 1367, que dice así: "Las letras, en efecto, son instrumentos de locura para muchos, de soberbia para casi todos, salvo que, cosa extraña, terminen descansando en un alma buena y bien dispuesta» (Citado por Llovet, 2011, p. 261). Realmente ignoro en qué consiste tener un "alma buena", pero imagino que un alma así es una que es prudente y modesta, magnánima y, añado yo, que sabe de verdad escuchar lo que el otro dice. Un alma que sabe, de modo amable y cortés - aunque lo cortés no quite lo valiente-conversar. El estudio nos permite que la conversación entre las generaciones prosiga a lo largo del tiempo. Pero hoy nuestras instituciones universitarias están siendo vampirizadas por un proceso de infantilización que, como un virus letal, afecta tanto a jóvenes como a adultos, a estudiantes y a profesores, un virus que impide dicha conversación. El estudio invita al desacuerdo razonable, y eso permite, insisto, que la conversación se mantenga y se profundice. El desacuerdo invita a la discusión, mientras que la declaración "Me siento ofendido" la clausura de forma bochornosa y definitiva. Vivimos tiempos de conversaciones imposibles. A algunos de nosotros esto nos conduce a la melancolía, que es una pena que no tiene nombre: por eso nos encerramos a leer los libros que más amamos y a escribir en nuestros cuadernos de notas, a conversar de nuestras cosas con los pocos amigos que verdaderamente lo son y, mientras leemos a los clásicos, mantener una conversación con los difuntos. Cuando algunas de esas instituciones universitarias de las que hablo terminan por brindar espacios de relajación con juguetes blandos y mascotas para los estudiantes que sufren estrés ante los exámenes y otras ansiedades asociadas, sin duda, algo está pasando que debería darnos... a estudiar.

\section{REFERENCIAS BIBLIOGRÁFICAS}

Agamben, G. (1989). Idea de la prosa. Barcelona: Península.

Agamben, G. (2017). El uso de los cuerpos. Homo Sacer, IV:2. Valencia: Pre-Textos.

Agamben, G. (2018). Autorretrato en el estudio. Buenos Aires: Adriana Hidalgo.

Arendt, H. (2002). La vida del espíritu, Barcelona: Paidós.

Arsenjuk. L. y Koerner, M. (2009). Study, Students, Universities: An Introduction. Polygraph, 21, 1-13.

Azorín (2007). Confesiones de un pequeño filósofo. Madrid: Espasa-Calpe. 
Bacon, F. (1990). Essais de morale et politique. París: L'Àrche.

Backer, D. I. y Lewis, T. E. (2015). The Studious University. Cultural Politics, 11(3), 229-345. https://doi.org/10.1215/17432197-3341936

Barthes, R. (2005). La preparación de la novela. Notas de cursos y seminarios en el Collège de France, 1978-1979 y 1979-1980. Buenos Aires: Siglo XXI editores.

Biesta, G. (2011). Aprendiz, estudiante, hablante. ¿Por qué importa cómo llamamos a quiénes enseñamos? En G. Cornelisen, J. Larrosa y J. Masschelein (Eds.) Jacques Rancière. La educación pública y la domesticación de la democracia (pp. 149-173). Buenos Aires: Miño y Dávila Editores.

Biesta, G. (2015). Against learning. Reclaiming a language for education in an age of learning. Nordisk Pedagogik, 25, 54-66. https://doi.org/10.4324/9781315635811

Bourdieu, P. (2003). Méditations pascaliennes. París: Éditions du Seuil.

Bordelois, I. (2017). Etimología de las pasiones. Buenos Aires: Libros del Zorzal.

Citati, P. (2008). Ulises y la Odisea. El pensamiento iridiscente. Barcelona: Galaxia GutenbergCírculo de Lectortes.

Claire, J. (2006). La mélancolie du savoir. En Autor (Dir.) Mélancolie, génie et folie en Occident (pp-202-208). París: Galeries nationales de Grand Palais.

Comenius, I. A. (2018). Orbis sensualium pictus (El mundo en imágenes). Barcelona: Libros del zorro rojo.

D’hoest, F. (2015). El aprendizaje: del signo a la ficción. Tesis doctoral: Madrid-UCM.

Dictionnaire Littré, París: Le livre de poche, 1990.

Emerson, R. W. (2015). Diarios. Madrid : Ápeiron ediciones.

Flaubert, G. (2009). Querida maestra. Escritoras en la correspondencia de Gustave Flaubert. Córdoba: El Olivo Azul.

Földényi, L. (1986). Melancolía. Barcelona: Galaxia Gutenberg-Círculo de Lectores.

Freire, P. (2001). La importancia de leer y el proceso de liberación. México: Siglo XXI editores.

Foucault, M (2001). LiHerméneutique su sujet. Cours au Collège de France, 1981-1982. París: Gallimard-Seuil.

Flor, de la, F. R. y Escandell, D. (2014). El gabinete de Fausto. Madrid: CSIC.

Fumaroli, M. (2013). La República de las letras. Barcelona: El Acantilado.

Garcés, M. (2015). Filosofía inacabada. Barcelona: Galaxia Gutenberg.

Greish, J. (2015). Vivre en philosophant. París : Hermann.

Guitton, J. (2010). El trabajo intelectual. Madrid: Rialp.

Hadot, P. (2001). La philosophie comme manière de viure. París: Albin Michel.

Hadot, P. (2006). Ejercicios espirituales y filosofía antigua. Madrid: Siruela.

Handke, P. (2018). La doctrina del Sainte-Victoire. Madrid: Alianza.

Hodgson, N. (2016). The Researcher and the Studier: On Stress, Triednes and Homelessness in University. Journal of Philosophy of Education, 50(1), 37-48. https://doi.org/10.1111/14679752.12171

Homero (2004). Odisea. Madrid: Alianza Editorial. Versión de Carlos García Gual.

Horacio (2016). Sátiras. Epístolas. Arte poética. Edición bilingüe de Horacio Silvestre. Madrid: Cátedra. 
Illich, I. (2002). En el viñedo del texto. Etología de la lectura: un comentario al "Didascalicon" de Hugo de San Victor. México: FCE.

Jullien, F. (2016). Lo intimo. Lejos del ruidoso amor. Buenos Aires: El Cuenco de Plata.

Joubert, J. (2009). Pensamientos. Barcelona: Península.

Larrosa, J. y Rechia, K. (2018). P de profesor. Buenos Aires: Noveduc.

Larrosa, J. (2018). Esperando năo se sabe o quê. Sobre o oficio de profesor. Belo Horizonte: Autêntica.

Larrosa, J. (2019). Esperando no se sabe qué. Sobre el oficio de profesor. Barcelona: Candaya.

Lepenies, W. (2007). ¿Qué es un intelectual europeo? Los intelectuales y la política del espíritu en la historia europea. Barcelona: Galaxia Gutenberg-Círculo de Lectores.

Lewis, T. (2003). On study: Giorgio Agamben and educational potentiality. New York: Routledge.

Llovet, J. (2011). Adiós a la Universidad. El eclipse de las humanidades. Barcelona: Galaxia Gutenberg- Círculo de Lectores.

MacIntyre. A. (1987). Tras la virtud. Barcelona: Crítica.

Maquiavelo, N. (2009). Antología. Barcelona: Península.

Marx, W. (2009). Vie du lettré. París: Les Éditions de Minuit.

Masschelein, J. (2001). The Discourse of the Learning Society and the Loss of Childhood. Journal of Philosophy of Education, 35(1), 1-20. https://doi.org/10.1111/1467-9752.00206

Montaigne, M. (2007). Los Ensayos. Barcelona: El Acantilado. Edición a cargo de J. Bayod Brau, según la edición de 1595 de Marie de Gournay.

Morey, M. (2007). Cuaderno de notas. En Autor, Pequeñas doctrinas de la soledad (pp. 355-358). México: Sexto Piso.

Nehamas, A. (2005). El arte de vivir. Reflexiones socráticas de Platón a Foucault. Valencia: Pre-Textos.

Ortega y Gasset, J. (1974). Unas lecciones de Metafísica. Madrid: Ediciones de la Revista de Occidente-El Arquero.

Pardo, J. L. (1996). La intimidad. Valencia: Pre-Textos.

Pascal (2005). Pensamientos. Madrid: Valdemar.

Pavie, X. (2012). Exercices Spirituels. Leçons de la philosophie antique. París: Les Belles Lettres.

Pérez Cortés, S. (2004). Palabras de filósofos. Oralidad, escritura y memoria en la filosofía antigua. México: Siglo XXI Editores.

Pieper, J. (2017). El ocio y la vida intelectual. Madrid: Rialp.

Platón (1999). Diálogos V: Parménides, Teeteto, Spfista, Político. Madrid: Gredos.

Proust, M. y Rivière, J. (2017). Correspondencia 1914-1922. Segovia: La Uña Rota.

Proust, M. (1989). À la recherche du temps perdu, IV. Le Temps retrouvé. París : GallimardBibliothèque de la Pléiade.

Proust, M. (2003). En busca del tiempo perdido, 7 volúmenes. Barcelona: Mondadori. Traducción: Carlos Manzano.

Reboul, O. (1980). Qu'est-ce qu'apprendre? París: Puf.

Ripa, C. (1996/ 1593). Iconología, Vol. II. Madrid: Akal. Traducción del Italiano: J. Barja e Y. Barja. Traducción del latín y griego: R. M. Mariño Sánchez-Elvira y F. García Romero. Prólogo: A. Allo Manero. 
Ruitemberg, C. (2017). Reconceptualizing Study in Educational Discourse and Practice Routledge. Routledge: Taylor \& Francis Group. https://doi.org/10.4324/9781315652214

Rocha, S. (2015). Folk Phenomenology: Education, Study, and the Human Person. Eugene OR: Pickwick.

San Víctor, H. de (2011). Didascalicon de studio legendi (El afán por el estudio). Madrid: BAC. Edición bilingüe.

Sánchez Ferlosio, R. (2011). La forja de un plumífero. En Autor, Carácter y destino. Ensayos $y$ artículos escogidos (pp. 383-402). Chile: Ediciones Universidad Diego Portales.

Sarlo, B. (2015). Apuntes de la novela que Barthes no escribió. https://semanariouniversidad. $\mathrm{com} /$ suplementos/loslibros/apuntes-de-la-novela-que-barthes-no-escribio/ (Consultado el 08/04/2019).

Séneca. L. A. (2013). Sobre la brevedad de la vida, el ocio y la felicidad. Barcelona: El Acantilado. Séneca (2018). Cartas a Lucilio. Madrid: Cátedra.

Schlanger, J. (1997). La vocation. París: Seuil.

Simons, M. y Masschelein, J. (2014). Defensa de la escuela. Una cuestión pública. Buenos Aires: Miño y Dávila.

Sloterdijk, P. (2012). Has de cambiar tu vida. Valencia: Pre-Textos.

Tatián, D. (2017). Apunte sobre la vida de los estudiantes y el estudio como forma de vida. En Lo interrumpido (pp. 81-92). Buenos Aires: Editorial Las cuarenta.

Thornton, D. (1997). The Scholar in his Study. New Haven and London: Yale University Press.

Valéry, P. (2017). Cahiers, 1. París: Gallimard-Bibliotèque de La Pléiade. Edición a cargo de Judith Robinson-Valéry. 
